\title{
Ranch Values and the Federal Grazing Fee
}

DAVID K. LAMBERT

\section{Abstract}

Past analysis of the impacts of higher federal graxing fees on ranch values have been purely speculative due to the absence of observations on sales of Western cattle ranches under a wide range of fee levels. An income approach to ranch value determination is described here in which numerous parameters affecting value can be varied. Solutions attained under different grazing fees are capitalized into the net present value of a potential ranch investment. Substantial decreases in ranch revenues and ranch values can occur with large fee increases in cases where public land forage comprises a large share of a ranch's annual forage supply.

\section{Key Words: grazing fees, public lands}

Many factors affect the purchase price of a Western beef cattle ranch. The productivity of the ranch and the expected distribution of future cattle prices influence potential income. Estimates of the costs of production, including the federal grazing fee on public land-dependent ranches, are subtracted from gross revenues to provide an estimate of expected annual before-tax net revenues. Adjusting these estimates by expected inflation rates, changes in land and cattle asset values, applicable tax rates, and interest and opportunity costs of investment capital results in an estimate of the net present value of the ranch investment.

Changes in the expected production, price, and cost relationships affect the present value calculations. The purpose of this paper is to explore how changes in one of the costs of production affect net present value. Specifically, how do changes in the fee charged for grazing cattle on public rangelands affect ranch values? Expected after-tax net present value is calculated as a random variable under different grazing fee levels with stochastic livestock prices. The influence of alternative federal grazing fee levels on the distribution of annual revenues and on ranch net present value is analyzed.

The paper is organized into 5 sections. Following the introduction is a brief review of the literature addressing rural land valuation approaches, with specific reference to factors hypothesized to affect ranch land. The third section describes the model developed during this study to determine ranch values using the income approach to rural land valuation. The fourth section of the paper discusses the procedures developed to incorporate the stochastic nature of livestock prices into what are normally deterministic, nonrandom approaches to estimating ranch values. The empirical procedures employed and the results of changing parameter values on ranch values are discussed next. The paper concludes with a discussion of the results and the implications for those involved in the grazing fee debate.

\section{Background}

Three major approaches exist for the valuation of rural land property: (1) the income capitalization approach; (2) the comparable sales approach; and (3) the cost approach (American Institute of Real Estate Appraisers 1983). The cost approach, which is based primarily on the replacement costs of buildings and other improvements, has little applicability to a Western beef cattle ranch, in which most of the value derives from the land resource.

Comparable sales approaches base land values on information derived from sales of similar ranch parcels in the area. Although preferred for determination of actual sales values, the absence of recent ranch sales data under differing fee levels precludes this

\footnotetext{
Author is assistant professor, Department of Agricultural Economics, University of Nevada, Reno 89557-0004.

Manuscript accepted 26 March 1987.
}

approach for assessing ranch values under alternative parameter specifications.

Given this absence of market sales observations, changes in ranch values with different production cost assumptions can be determined using the income capitalization approach to rural land appraisal (American Institute of Real Estate Appraisers 1983). This procedure capitalizes all expected future income streams into a net present value of the investment opportunity. The calculations can be adjusted for alternative levels of future production characteristics and output price and input cost relationships. This approach is ideally suited for assessing the sensitivity of ranch value to changes in these parameters.

Discrepancies may exist between income capitalization values and actual ranch sales values (Pope 1985, Martin and Jefferies 1966). Observed sales prices may incorporate values other than those affecting the ranch's resources in production. Market value and income approaches are similar when agricultural uses predominate (Madsen et al. 1982, Torell and Fowler 1986). To the extent that the results reported in this paper represent cattle ranches having little alternative development potential, the results accurately portray impacts of changing fees on ranch values.

Although there has been speculation on the impacts of different fee levels on ranch values (USDA/DI 1986, McCarl and Brokken 1985), little empirical work has been done to measure the magnitude of the impacts. Demand models of Western cattle ranches have estimated the contribution of federal grazing permits of a certain size to market price (Collins 1983, Winter and Whittaker 1981). The lack of cross-sectional observations under a range of different fee levels has precluded the estimation of models investigating the fee/selling price relationship. The model presented in the next section allows such determinations to be made.

\section{The Ranch Purchase Model}

The determination of ranch prices in a perfectly competitive environment would consider all factors influencing the profitability of the ranch unit. The ranch's expected annual net returns, tax considerations from the purchase and ownership of the ranch's assets, interest payments and potential capital gains, expected appreciation in the value of the ranch, and the opportunity cost of the purchaser's own capital in an alternative investment will determine the value of the ranch as a productive asset (Hopkin et al. 1973). These components will be added successively to a simple investment model to attain the model used in this study.

A simple investment model establishes the net present value (NPV) of the investment's expected net revenue stream as the maximum acceptable purchase offer (PO):

$$
P O \leq N P V=A_{t / n}(R-C)+S P_{L}(1+f)^{-n}
$$

In this formulation, net revenues $(\mathrm{R}-\mathrm{C}$, or revenues minus variable costs) ${ }^{1}$ are treated as constant over the $n$ years of the investment. The present value of this annuity is calculated using the discount factor $A_{\ell / n}$. The variable fis interpreted as the opportunity cost of purchaser's capital, adjusted for inflation in the manner described in Castle and Hoch (1985). The final term on the right hand side of equation (1) represents the present value of the resale value of the ranch $\left(S_{\mathrm{L}}\right)$ in year $n$, discounted at the rate of discount $f$. 'Fixed costs are ignored in equation (1). Fixed costs associated with the investment
will be added as the model is developed. 
The components of equation (1) are subject to taxation. Annual income is taxed at the average tax rate of $T_{0}$. Forty percent of the net capital gain resulting from the sale of the ranch at the end of the planning horizon may be subject to taxation. ${ }^{2}$ Present value of the net gain from the ranch sale in year $n$ will equal the sale price minus taxes paid on any capital gain.

Adding taxes on net annual income and on future capital gains to equation (1) yields:

$$
P O \leq N P V=A_{\ell / n}(R-C)\left(1-T_{0}\right)+\left(1+f^{-n}\left(S_{L}^{T}\right)\right.
$$

where $S P_{L}^{T}$ represents salvage value of the ranch land in year $n$, adjusted for capital gains tax.

Interest payment on investment capital is considered a business expense and is thus subtracted from income in calculating taxable income. Average annual interest payments on capital borrowed to purchase a ranch, $\mathrm{I}_{\mathrm{L}}$, are adjusted for tax savings resulting from these interest payments, or $I_{L} T_{0}$.

The purchase of cattle adds an interest cost and a salvage value to the equation similar to that for the ranch itself. The average annual interest cost of the cattle purchase is presented by Is. Adding tax savings resulting from interest payments on the ranch and livestock investment for $p, m$, and $n$ years, and the after-tax resale value of the stock, SPs ${ }^{2}$, in year $n$ to equation (3) gives: ${ }^{3}$

$$
\begin{aligned}
P O \leq N P V= & A_{t / p}\left((R-C)\left(1-T_{0}\right)+I_{L} T_{0}+I_{0} T_{0}\right) \\
& +\left(A_{t / m}-A_{t / p}\right)\left((R-C)\left(1-T_{0}\right)+I_{L} T_{0}\right) \\
& +\left(A_{t / n}-A_{t / m}\right)\left((R-C)\left(1-T_{0}\right)+I_{L} T_{0}\right) \\
& +(1+f)^{-n}\left(S P_{L}^{T}+S P_{s}^{T}\right)^{4}
\end{aligned}
$$

Investments in depreciable assets (e.g., bulls, machinery, equipment) are calculated on an annualized basis utilizing concepts of capital budgeting discussed in Baumol (1977). Several simplifying assumptions are made. First, straightline depreciation is assumed. Second, salvage value is assumed to be zero (i.e., resale value is totally accounted for in depreciation). Third, an average number of

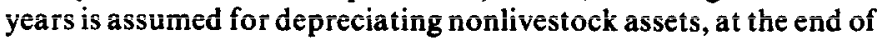
which the investment cycle is repeated.

The annualized cost for investment in nonlivestock depreciable assets is represented as $\mathrm{AC}_{\mathrm{NL}}$. Annualized bull investment costs are calculated in a similar manner, yielding $\mathrm{AC}_{\mathrm{B}}$. Cows are treated differently in the calculations. Purchased cows are depreciated over the first 5 years, represented DEP , with subsequent cows in the herd assumed to be nondepreciable replacements.

The initial cow purchase is also entitled to the $10 \%$ investment tax credit (represented ITC $_{\mathbf{s}}$ ), realized at the end of the first year. The purchaser's share of the initial outlay for the cattle, COST, also enters as a first-year cost.

Adding these terms to equation (3) yields the complete after tax model of the ranch purchase decision:

$$
\begin{aligned}
& P O \leq N P V=A_{t / p}\left((R-C)\left(1-T_{0}\right)+I_{L} T_{0}+I_{L} T_{0}+I_{g} T_{0}\right) \\
& +\left(A_{/ / m}-A_{/ / p}\right)\left((R-C)\left(1-T_{0}\right)+I_{L} T_{0}\right) \\
& +\left(A_{t / n}-A_{2 / m}\right)(R-C)\left(1-T_{0}\right) \\
& +(1+f)^{-n}\left(S_{L}{ }^{T}+S_{P s}{ }^{T}\right) \\
& +A_{t / n} A C_{N L} A_{t / n} A C_{B} \\
& +A_{t / 5}\left(D_{E P}\right) T_{0}+1 \mathrm{TC}_{\mathrm{B}}+\operatorname{COS} \mathrm{T}_{\mathrm{g}}
\end{aligned}
$$

Setting the purchase offer, PO, equal to net present value (NPO) allows the equation to be explicitly solved, after rearrangement, for maximum PO. The resulting value represents the maximum amount that can be paid while still receiving the purchaser's desired real rate of return.

2Tax treatment of capital gains will change with implementation of the 1986 Tax Reform Act. The model is currently being revised to reflect these changes. Due to the uncertainty surrounding future tax treatments of investment credits and capital gains, the model investigates the ranch invest ment under tax structure in place through 1986. ${ }^{3}$ It is assumed that the term of the livestock loan is less than or equal to the real estate loan which, in turn, is less than or equal to the planning horizon, or $p \leq m \leq n$. 4Tax rates, $T_{0}$, will differ among periods 0 to $\mathrm{p}, \mathrm{p}$ to $\mathrm{m}$, and $\mathrm{m}$ to $\mathrm{n}$ based on different interest deductions from gross income. The model accounts for these differences by explicitly calculating the effective tax rate for each period. Attempts to retain some notational simblicity lead to the use of the constant $T_{n}$ notation in this section.

\section{Data-Cattle Prices}

Cattle prices, like most agricultural output prices, vary considerably from period to period. The use of average values in economic models ignores this parameter variability and results in deterministic solutions yielding no information on the riskiness of the investment. For decision makers averse to risk, average value solutions are inferior to solutions presenting the probabilities of different outcomes. The model used in this study incorporates the uncertainty surrounding cattle prices.

Cattle prices for the second week of November were collected for

\begin{tabular}{|c|c|c|c|c|}
\hline & $\begin{array}{c}\text { Mean } \\
\text { (\$/cwt) }\end{array}$ & $\begin{array}{l}\text { Standard } \\
\text { deviation }\end{array}$ & $\begin{array}{l}\text { Coefficient } \\
\text { of skewness }\end{array}$ & $\begin{array}{l}\text { Coefficient } \\
\text { of kurtosis }\end{array}$ \\
\hline Steers & 92.26 & 22.37 & $\begin{array}{c}0.70 \\
(1.68)^{*}\end{array}$ & $\begin{array}{c}-0.53 \\
(-0.64)\end{array}$ \\
\hline Heifers & 78.23 & 21.23 & $\begin{array}{c}0.62 \\
(1.49)\end{array}$ & $\begin{array}{c}-0.61 \\
(-0.74)\end{array}$ \\
\hline Cows & 48.88 & 11.99 & $\begin{array}{l}0.84 \\
(2.04)^{* *}\end{array}$ & $\begin{array}{c}0.02 \\
(0.02)\end{array}$ \\
\hline Bulls & 60.95 & 11.34 & (1.61) & $(-0.45)$ \\
\hline
\end{tabular}
the period 1950-84. Kansas City prices were used for light steers and heifers (3-400 pounds), and Omaha prices for bulls and utility cows were used. 5 The choice of November prices was based on observed sales dates for most Western ranchers (Gilliam 1984). Kansas City and Omaha prices were used by default: no complete price series exists for Nevada.

The price series were deflated to 1984 dollars using the consumer price index. Sample characteristics of the 4 price series are reported in Tables 1 and 2.

\section{Table 1. Sample characteristics of the original deflated price series.}

$t$-values are in parentheses

- signifies significant at the $90 \%$ level

* - signifies significant at the $95 \%$ level

Table 2. Sample correlation coeficients of the original deflated price series.

\begin{tabular}{lclll}
\hline \hline & Steers & Heifers & Cows & Bulls \\
\hline Steers & 1.00 & & & \\
Heifers & 0.98 & 1.00 & & \\
Cows & 0.94 & 0.97 & 1.00 & \\
Bulls & 0.92 & 0.93 & 0.97 & 1.000 \\
\hline
\end{tabular}

The deflated price data were tested to estimate an appropriate parent distribution from which to draw random prices for the model. The hypothesis of multivariate normality of the joint distribution was rejected using the Shapiro-Wilks procedures for testing multivariate distributions (Malkovich and Afifi 1973, Shapiro and Wilks 1965).

All 4 price series were found to be skewed to the right. The separate series were thus individually tested to determine if they could have come from Beta distributions. A method of moments based search procedure was conducted using standardized values of the deflated prices to estimate integer values for the 2 parameters of the Beta distribution.

A Kolmogorov-Smirnoff nonparametric test was conducted to determine if the 4 empirical probability density functions (pdf) could have come from the pdf's based on the calculated $\alpha$ and $\beta$ parameters (Conover 1971). In all 4 price series, it could not be rejected that the samples were drawn from the calculated pdf's.

The IMSL statistical package subroutine GGBTR was used to generate 250 random draws from the appropriate Beta distributions. The random variates (distributed over the 0 to 1 range) were linearly transformed to approximate the sample characteristics for

SPrice data were obtained from various issues of the Livestock Market News, a weekly publication of the Livestock Division, Agricultural Marketing Service, U.S. Department of Apriculture. 
Table 3. Base values for parameters affecting ranch net present value.

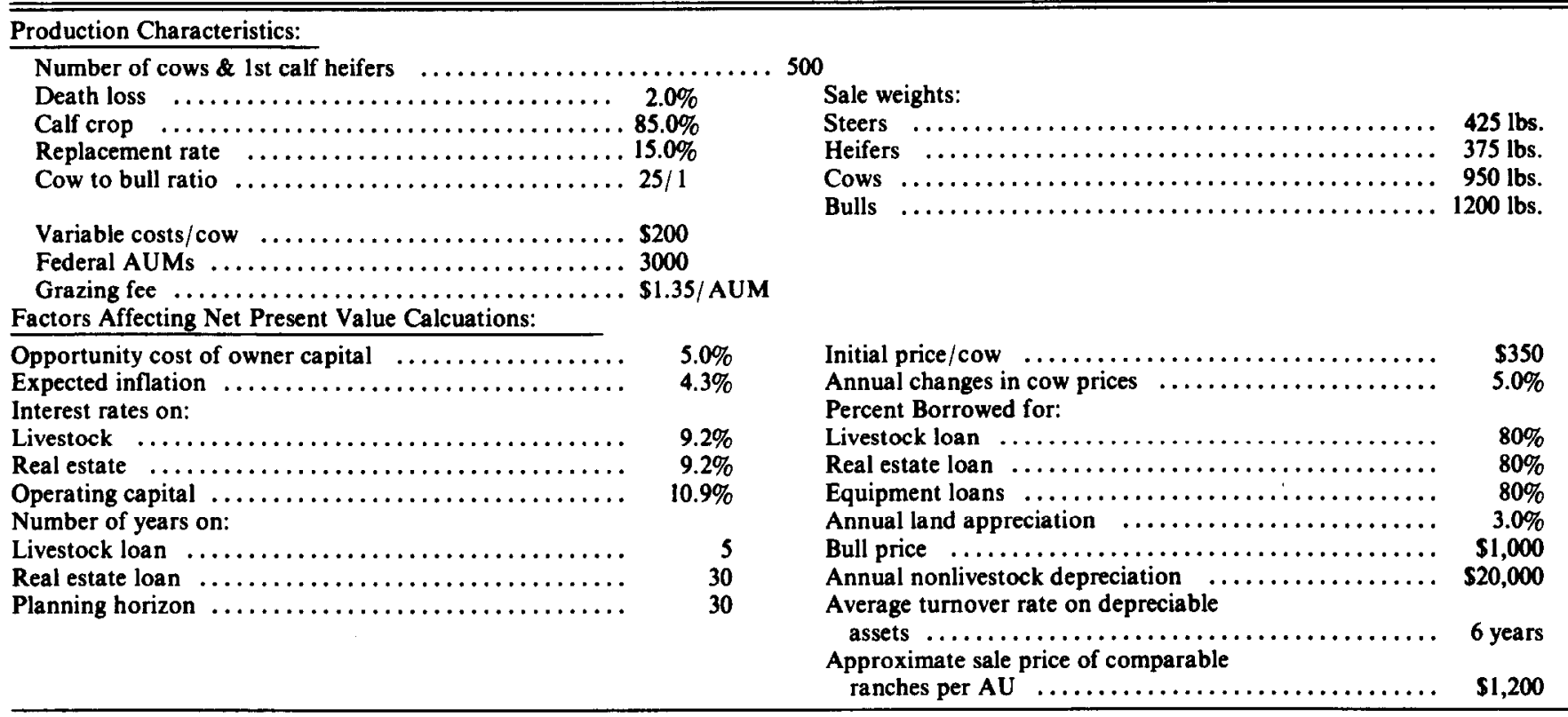

the individual price series. A pairwise sorting program was used to sort the individual series to approximate the correlation relationships of the original price series.

\section{Empirical Procedures}

An interactive computer program was written in BASIC that solved the ranch net present value problem (equation 4). Thirty parameter values are entered by the user. Results are reported in probabilistic terms. Annual net returns resulting from the stochastic livestock prices are reported in fractiles (i.e., net returns are reported as the minimum and at the $0.2,0.4,0.6,0.8$, and 1.0 levels of the sample distribution function). The expected value of the ranch net present value random variable is presented together with the upper and lower confidence limits at the $95 \%$ level.

Parameter values used for assessing the impact of different fee levels are shown in Table 3. These ranch characteristics were derived from Northeastern Nevada enterprise budget sheets (Myer and Torell 1983). Land appreciation rates and capital costs were developed from secondary sources (Amols and Kaiser 1984). Subsequent runs were made with changes made only in the grazing fee.

\section{Results-Impacts of Different Fee Levels on Ranch Values}

The principal goal of this study was to test the sensitivity of ranch net present value to changes in the federal grazing fee. Net present value calculations were conducted for fees ranging from the 1985 grazing fee of $\$ 1.35$ per AUM up to $\$ 12.00$ per AUM.

As the fee increased, the distribution of ranch net present value decreased (Fig. 1). Mean values ranged downwards from $\$ 805,284$ (or $\$ 1,611$ per AU) at the $\$ 1.35$ grazing fee. This expected decline in net present value results from the reliance of the calculations upon the value of the discounted net income streams. As costs increase, net annual income decreases in this model which allows no adjustments in the size of the federal permit (Fig. 2).

Changes in the federal grazing fee exert influences of differing magnitude on ranch revenues and on the net present value of a potential ranch investment. For a ranch characterized by the parameters posited in Table 3, a 1\% increase in the current fee of $\$ 1.35$ per AUM results in a reduction in mean net revenues of $0.09 \%$. Thus, an increase in fees from $\$ 1.35$ to $\$ 1.36$ reduces mean net revenue by $\$ 32$, or about 6 cents per head.

Grazing fee increases have less of an influence on net present ranch values from the perspective of a prospective purchaser due

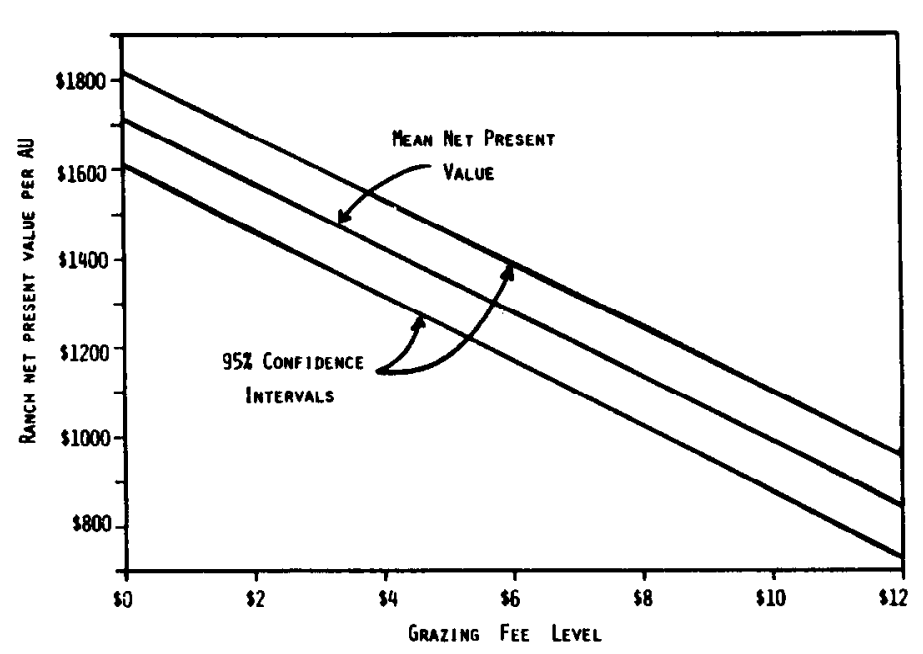

Fig. 1. Effects of grazing fee levels on ranch net present value.

to the influence of factors other than annual net revenues from the cow herd (e.g., investment tax credits, tax savings from interest payments). At the $\$ 1.35$ fee, a $1 \%$ increase in the fee reduces the mean net present value by $0.06 \%$, or about two-thirds of the fee increases' impact on net revenues.

Substitution of alternative forage sources or use of different management options as fee costs increase were not considered in the model. Such substitution would reduce the impact of fee changes on both revenue and ranch values. The results may, however, be applicable to a large area of the Western United States where management responses to fee increases are limited. The vehemence with which public land-dependent ranchers oppose fee increases are understandable given the results of this exercise. An increase in the grazing fee to levels comparable to the private grazing land lease rate would have severe income and capital consequences to permit holders. Given the parameter values used for these model solutions, a fee increase to the average 1985 private land lease rate of $\$ 8.40$ would reduce mean net ranch revenues from $\$ 92.62$ per $A U$ to $\$ 47.99$. Ranch values, based on the net present value calculations, would fall from $\$ 1,611$ per $A U$ at the 


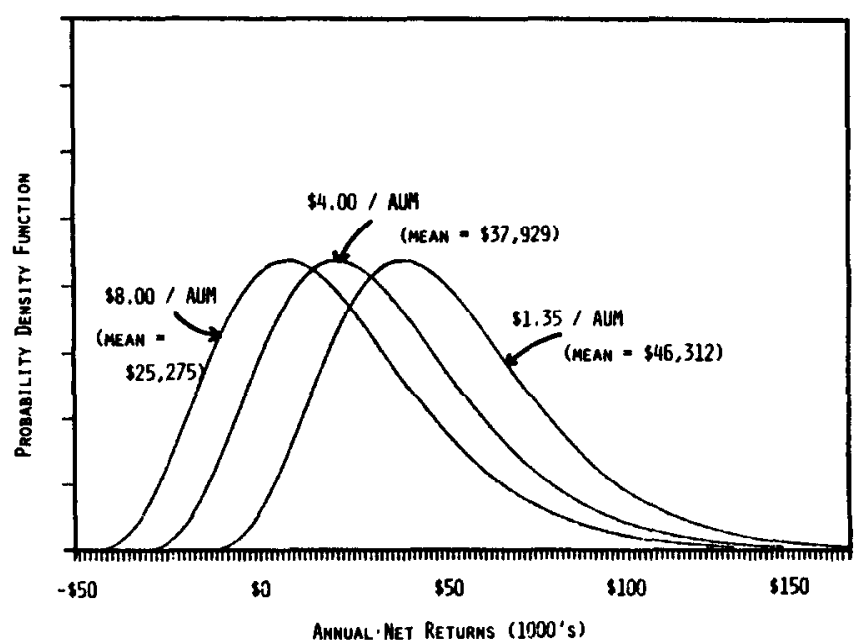

Fig. 2. Effect of grazing fee level on distribution of expected annual net returns.

$\$ 1.35$ fee to $\$ 1,105$. Capitalization of the revenue effects into ranch values would result in further depression in the sales value of public land dependent ranches.

\section{Summary}

A detailed model to calculate the expected after-tax annual net revenues and net present value of a ranch investment opportunity was described in this paper. Results of model testing indicate that ranch values are very sensitive to parameter values affecting net present value.

Increasing grazing fees from their current levels increased operating costs. The resulting decrease in annual net returns was capitalized into a lower expected net present value when no substitution of federal forage was allowed. The results demonstrated, however, that impacts were greater on annual net returns than on capitalized ranch values calculated on an income basis. Distribution of grazing fee increase impacts would thus affect current owners of public land-dependent ranches to a greater extent than future entrants into the industry. Future ent rants would pay lower prices for these ranches due to the knowledge of reduced future net returns.

\section{Literature Cited}

American Institute of Real Estate Appraisers. 1983. The appraisal of rural property. Amer. Inst. of Real Estate Appraisers, Chicago, Ill.

Amols, G., and W. Kaiser. 1984. Agricultural finance statistics, 1960-83. Stat. Bull. No. 706, USDA, U.S. Government Printing Office, Washington, D.C.

Baumol, William J. 1977. Economic theory and operations analysis, fourth edition. Prentice Hall, Inc. Englewood Cliffs, N.J.

Castle, E.M., and J. Hoch. 1985. Farm real estate price components, 1920-78. Amer. J. Agr. Econ. 67:794-805.

Collins, A.R. 1983. A ranch land price model for Wyoming. Wyoming Agr. Exp. Sta. Rep. SM 44R.

Conover, W.J. 1971. Practical nonparametric statistics. John Wiley \& Sons, Inc. New York.

Gilliam, Henry C. 1984. The U.S. beef cow-calf industry. Econ. Res. Serv., USDA, Agr. Econ. Rep. No. 51

Hopkin, J.A., P.J. Barry, and C.B. Baker. 1973. Financial management in agriculture. Interstate Printers and Publishers, Inc., Danville, III.

Madsen, A.G., C.K. Gee, and J.B. Keffeler. 1982. Market vs. productive value of Colorado ranches. J. Amer. Soc. Farm Mgrs. and Rural App. 46:19-23.

Malkovich, J.F., and A.A. Afin. 1973. On tests for multivariate normality. J. Amer. Stat. Ass. 68:176-9.

Martin, William E., and G.L. Jefferies. 1966. Relating ranch prices and grazing permit values to ranch productivity. J. Farm Econ. 48:233-42.

McCarl, Bruce A., and R. Brokken. 1985. An economic analysis of alternative grazing fee systems. Amer. J. Agr. Econ. 67:769-78.

Myer, G.L., and D.J. Torell. 1983. Costs and returns for cow-calf enterprise in Eureka county, Nevada. Nevada Coop. Ext. Serv., E-35-83, Reno Nev.

Pope, C. Arden. 1985. Agricultural productive and consumptive use components of rural land values in Texas. Amer. J. Agr. Econ. 67:81-6.

Shapiro, S.S., and M.B. Wilks. 1965. An analysis of variance test for normality (complete samples). Biometrika 52:591-611.

Torell, L.A., and J.M. Fowler. 1986. A model for predicting trends of New Mexico grazing land values. New Mexico Agr. Exp. Sta. B-723.

United States Department of Agriculture/Department of Interior. 1986. Grazing fee review and evaluation-final report 1979-1985.

Winter, John R., and J.K. Whittaker. 1981. The relationship between private ranchland prices and public land grazing permits. Land Econ. 57:414-21. 